\title{
Spatio-temporal variation of microphytobenthos biomass, diversity and assemblage structure in the Loire Estuary, France
}

\author{
Lourenço Ribeiro ${ }^{1,2, *}$, Ismaïl Benyoucef ${ }^{1}$, Michel Poulin ${ }^{3}$, Bruno Jesus ${ }^{1}$, \\ Philippe Rosa ${ }^{1}$, Vona Méléder ${ }^{1}$, GuoYing $\mathrm{Du}^{4}$, Laurent Barillé ${ }^{1}$ \\ ${ }^{1}$ Laboratoire Mer Molécules Santé (EA 2160), Faculté des Sciences et des Techniques, Université de Nantes, BP 92208 , \\ 44322 Nantes cedex 3, France \\ ${ }^{2}$ MARE-Marine and Environmental Sciences Centre, Faculdade de Ciências da Universidade de Lisboa, Campo Grande, \\ 1749-016 Lisbon, Portugal \\ ${ }^{3}$ Recherche et collections, Musée canadien de la nature, Ottawa, Ontario K1P 6P4, Canada \\ ${ }^{4}$ Key Laboratory of Marine Genetics and Breeding Ministry of Education, College of Marine Life Sciences, \\ Ocean University of China, Qingdao 266003, PR China
}

\begin{abstract}
Diatom-dominated microphytobenthos (MPB) communities of 4 intertidal mudflats along the meso- and polyhaline reaches of the Loire Estuary, France, were investigated during a year cycle. They were analysed in terms of biomass, diversity, species composition and growth form distribution. The assemblages of the 2 upstream sites were characterised by high biomass and lower diversities and were mostly dominated by epipelon. The 2 downstream, most haline sites had lower biomass and higher diversities and were dominated by both epipelon and tychoplankton. Diversity did not exhibit a clear seasonal signal in the upstream mudflats, but it was higher during the first half of the study in the downstream sites. The coexistence of 2 growth forms seems to increase diversity of the mudflat assemblages. Species distribution was mainly linked to changes in sediment texture and salinity, both with a marked seasonal variability. MPB biomass was inversely related to MPB diversity and positively related to both mud content and the epipelon. MPB diversity was not, however, significantly correlated with mud content. Slight changes in sediment texture, even if causing variations in assemblage composition, did not change overall diversity. The existence of an important and even dominant tychoplanktonic fraction could be considered a distinctive feature of these benthic environments in the Loire, as well as in other macrotidal estuaries.
\end{abstract}

KEY WORDS: Diatoms $\cdot$ Growth form $\cdot$ Tychoplankton $\cdot$ Navicula phyllepta $\cdot$ Macrotidal estuary

\section{INTRODUCTION}

Estuarine food webs rely largely on detrital organic matter (OM) and on benthic and planktonic microalgae (McLusky \& Elliott 2004). In turbid estuaries, low-light conditions limit phytoplankton growth (Monbet 1992, Gameiro et al. 2011), and microphytobenthos (MPB) may become the main estuarine microalgal primary producers (Underwood \& Kromkamp

${ }^{*}$ Corresponding author: llribeiro@fc.ul.pt
1999). These microalgal assemblages are frequently dominated by diatoms, although they may also include dinoflagellates, euglenids and cyanobacteria (MacIntyre et al. 1996). They colonise the extensive intertidal flat areas in estuaries and coastal areas that provide vital ecosystem services (Hope et al. 2020). The transient biofilms that cover the mudflat sediment surface during emersion periods are composed of a matrix of cells and associated extracellular poly-

(C) The authors 2021. Open Access under Creative Commons by Attribution Licence. Use, distribution and reproduction are unrestricted. Authors and original publication must be credited. 
meric substances, mostly exuded by motile diatoms during locomotion, which increases sediment stability (Paterson et al. 2003, Underwood \& Paterson 2003). In certain conditions, such as periods of wind-induced wave formation, biofilm resuspension strongly decreases MPB biomass (Blanchard et al. 2006) by transferring it to the water column, where it can represent up to $60 \%$ of all phytoplankton in estuarine and coastal areas (de Jonge \& van Beusekom 1992, Hernández-Fariñas et al. 2017).

Numerous studies on the spatial distribution and temporal variation of estuarine MPB biomass have been carried out in the past decades (Nedwell et al. 2016 and references therein). Some of the main factors influencing MPB biomass seasonality are light, nutrients, physical disturbance and grazing (Van Colen et al. 2014, Savelli et al. 2018). Contrastingly, studies on the taxonomic structure of the diatomdominated MPB communities have become scarcer (Park et al. 2014), particularly those covering spatial and temporal patterns of both MPB biomass and MPB assemblage structure (Ribeiro 2010). Intertidal diatom assemblage composition varies both seasonally and spatially, not only within estuaries but also between estuaries (Underwood \& Barnett 2006). These differences are mainly driven by the interaction of several biotic and abiotic parameters, such as salinity, temperature, light, sediment composition, nutrients or grazing (Oppenheim 1991, Sabbe 1993, Underwood et al. 1998, Hagerthey et al. 2002, Sahan et al. 2007, Du \& Chung 2009, Ribeiro et al. 2013).

Most research dealing with the spatial and seasonal distribution of benthic diatoms in coastal and estuarine intertidal areas worldwide has been mainly concentrated in western European and North American estuaries (Round 1971, McIntire \& Moore 1977, Trobajo \& Sullivan 2010). However, even in those well-known geographical regions, large swaths of marine coast and important estuaries remain insufficiently studied. This is the case of the French Atlantic coast, where the MPB community structures of areas like the Pertuis Charentais (Du et al. 2017) or the Bourgneuf (Méléder et al. 2007), Marennes-Oléron (Haubois et al. 2005) and Morlaix (Riaux \& Germain 1980, Riaux 1983) bays have already been described, while the large macrotidal estuaries (i.e. Seine, Loire and Gironde) are yet to be comprehensively surveyed. In the case of the Loire Estuary, Marchand \& Elie (1983) carried out the only available study on MPB biomass spatio-temporal distribution but did not include any information on diversity or species composition. Inversely, there were only 2 previous references that dealt exclusively with the taxonomy and distribution of benthic diatoms in the Loire Estuary (Tempère \& Peragallo 1907-1915, Rincé 1993). Therefore, the present study is the first to provide a contemporaneous overview of the spatial and seasonal patterns of both MPB biomass and assemblage structure on the Loire Estuary intertidal areas.

Focusing on temporal variation, the present study provides a detailed monthly characterisation of several facets of the MPB assemblages at 4 sites in 2 haline domains of the Loire Estuary, over a period of $1 \mathrm{yr}$. The community structure features included not only biomass and species composition but also assemblage diversity and growth form distribution, which are less frequently explored (Ribeiro et al. 2013). Consequently, our main research question was whether the expected spatial and seasonal changes in species composition or biomass could also be translated in shifts in assemblage diversity and growth form composition. We hypothesised that species seasonal dynamics would not affect diversity and growth form composition (Ribeiro 2010, Virta et al. 2020) but that the turnover in species composition along the salinity gradient may also cause changes in those descriptors of assemblage structure.

\section{MATERIALS AND METHODS}

\subsection{Site description}

The Loire Estuary is located on the French Atlantic coast and is about $100 \mathrm{~km}$ long, stretching from a freshwater portion, upstream of the city of Nantes, to the outer estuary downstream of Saint-Nazaire (Fig. 1). The Loire River has a drainage basin of $118000 \mathrm{~km}^{2}$, covering about one-fifth of the French territory. It is one of the main eutrophic European rivers (Moatar \& Meybeck 2005, Etcheber et al. 2007), but its nutrient loads have decreased since the 1990s (Ratmaya et al. 2019). It has an average flow rate of ca. $800 \mathrm{~m}^{3} \mathrm{~s}^{-1}$, ranging from $111 \mathrm{~m}^{3} \mathrm{~s}^{-1}$ during summer to $4760 \mathrm{~m}^{3} \mathrm{~s}^{-1}$ during winter floods (Ratmaya et al. 2019). Estuarine water residence time varies from less than $1 \mathrm{~d}$ during floods to $10 \mathrm{~d}$ during droughts. It is a macrotidal estuary, with $6 \mathrm{~m}$ average tidal amplitude at Saint-Nazaire, and its intertidal areas cover more than $30 \mathrm{~km}^{2}$. Most of them are located in the polyhaline domain, where salinity ranges from 18 to 30 , but also in the mesohaline reaches (salinity range: $5-18$ ), which extend upward to the Cordemais electric power station, where the oligohaline section of the estuary begins (i.e. salinity below 5). 


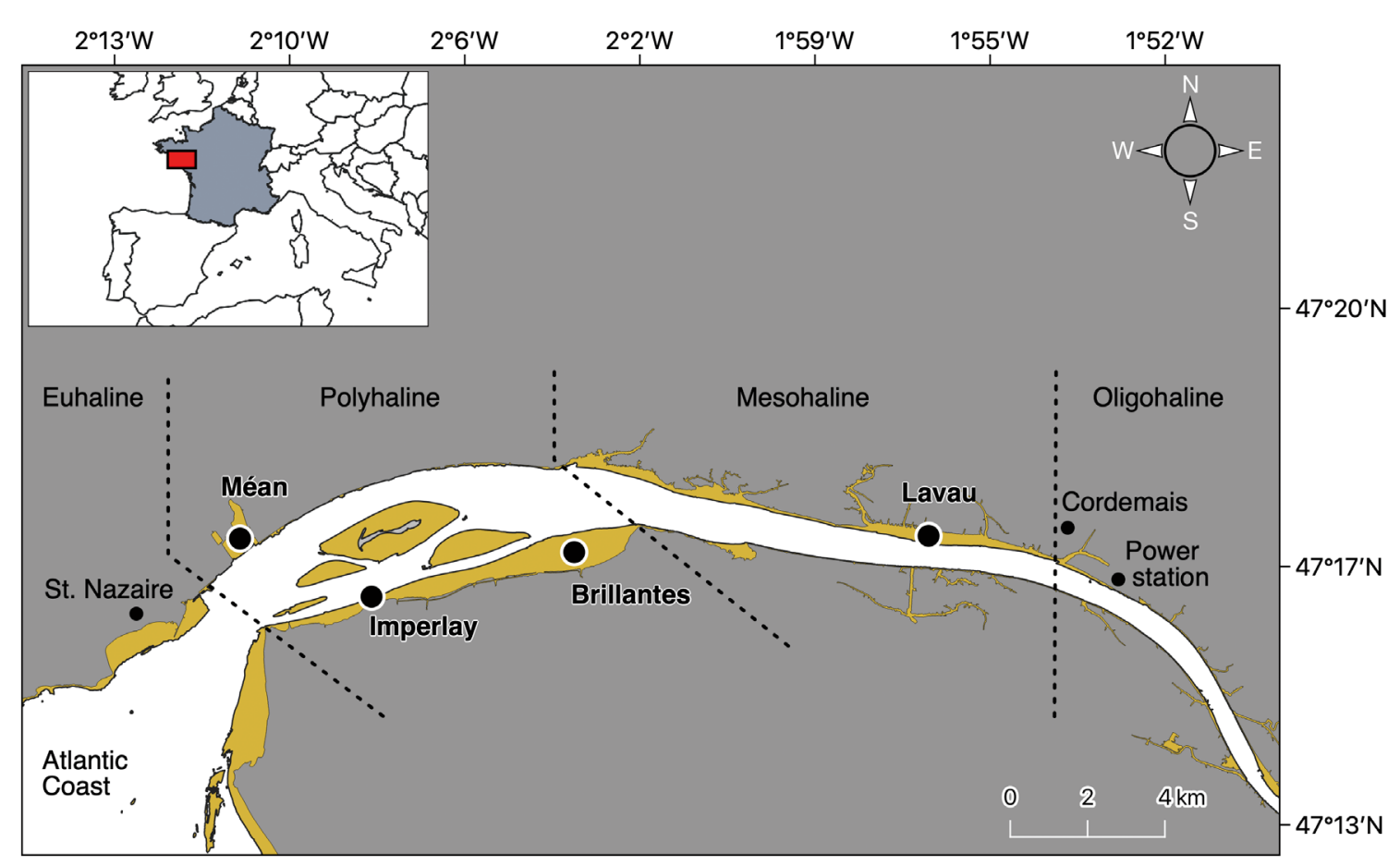

Fig. 1. Loire Estuary, France, with the 4 intertidal mudflats sampled in polyhaline (Méan, Imperlay, Brillantes) and mesohaline (Lavau) domains of the estuary. Intertidal flats in brown. Inset shows the position of the estuary on the west coast of France

This study was conducted in 4 different mudflats in the Loire Estuary. Three were located in the polyhaline section (Méan [MEA], Imperlay [IMP], Brillantes [BRI]), and the fourth (Lavau [LAV]) was located in the mesohaline domain (Fig. 1). The boundaries of each section have been set by decades of macrofaunal research in the Loire Estuary (e.g. Marchand \& Elie 1983). The bathymetry of the field sampling locations was between +4 and $+3 \mathrm{~m}$ above chart datum, corresponding to the middle tidal level of the mudflats. Remote sensing images showed that the MPB biofilms were concentrated at this bathymetric depth (Benyoucef et al. 2014). Each site was sampled during spring low tides, from January 2011 to January 2012. Sampling was performed every 2 mo during winter-spring and monthly during summer-autumn. This strategy follows that of Marchand \& Elie (1983), who observed that the widest MPB biomass variations occurred during summer.

\subsection{MPB sampling}

Surface sediment (upper $2 \mathrm{~mm}$ ) was collected using the contact corer method (Ford \& Honeywill 2002). At each sampling date, 9 contact cores were collected for pigment analysis and MPB biomass estimation. Two additional sediment cores were taken: one for taxonomic analysis and another for grain size analysis and for water and OM content determination. Samples were kept in liquid nitrogen in the field and stored at $-80^{\circ} \mathrm{C}$ in the laboratory prior to further analysis.

\subsection{Environmental parameters}

Particle size analysis of the sediment was made following Baize (2018) and using a Malvern Mastersizer $^{\circledR} 2000$ laser granulometer. This analysis allowed sediment textural groups to be defined by the relative percentages of mud (grain size $\varnothing<63 \mu \mathrm{m}$ ) and sand $(63<\varnothing<2000 \mu \mathrm{m})$, according to Udden-Wentworth's scale. Water content was determined as the percentage of water in relation to the total fresh sediment weight measured from contact cores. Sediment OM was measured as dry weight loss on ignition (BarilléBoyer et al. 2003). Water temperature and salinity were obtained from multiparameter probes from the network SYstème de Veille dans l'Estuaire de la Loire, which are operated by the Groupe d'Intéret Public Loire-estuaire and Electricité De France, and located near the sites: Cordemais (LAV), Paimboeuf (BRI) and Donges (MEA and IMP). Water temperature and salinity hourly data were averaged over a week before each sampling date. Air temperature and irradi- 
ance data were provided by Météo France from the Nantes-Bouguenais weather station. River flow rates, collected at the Direction régionale de l'Environnement, de l'Aménagement et du Logement station Montjean-sur-Loire, were averaged monthly. Water column dissolved inorganic nutrient concentration data (nitrate $\left[\mathrm{NO}_{3}{ }^{-}\right]$, phosphate $\left[\mathrm{PO}_{4}{ }^{3-}\right]$, dissolved silica [DSi]) were made available by the Loire Brittany River Basin Authority (http://osur.eau-loire-bretagne. fr/exportosur/Accueil).

\subsection{MPB biomass, pigment analysis and cell counts}

Microalgal biomass was estimated by sediment content in chlorophyll a ( $\mathrm{chl}$ a) and expressed in $\mathrm{mg} \mathrm{m}^{-2}$. Pigment extraction was performed on freezedried contact corer sediment samples with 95\% cold buffered methanol (Jesus et al. 2006). Identification and quantification of MPB pigments were made by HPLC following procedures explained in detail in Méléder et al. (2005).

The MPB assemblages were separated from the mineral fraction by an isopycnic separation method, described in Blanchard et al. (1988) and modified by Méléder et al. (2007), which uses the silica sol Ludox HS-40. Microscopic observations of the resulting extracts were made to check for the presence of microalgal groups other than diatoms (e.g. euglenids, cyanobacteria). To identify and count diatom cells, permanent slides of incinerated organic material $(4 \mathrm{~h}$ at $450^{\circ} \mathrm{C}$ in a muffle oven) mounted in Naphrax were made. Identification and cell counts were carried out under an Olympus AX70 microscope, with a minimum 400 diatom frustules counted per slide. Several references were used for diatom species identification (van der Werff \& Huls 1957-1974, Rincé 1993, Witkowski et al. 2000, Méléder 2003, Ribeiro 2010). Light microscopy observations were complemented with scanning electron microscopy (JEOL JSM 7600F). The relative species abundance was also calculated per site. Percentage of occurrence in samples was used to classify species as common (present in $>50 \%$ of samples), occasional (10-50\%), rare (4-10\%) and very rare (present in $<4 \%$ ). Diatom taxa were also assigned to 4 different growth forms, according to the classification proposed by Méléder et al. (2007) and Ribeiro (2010): epipelic (free living in the sediment), epipsammic (attached or closely associated with individual sand grains), tychoplanktonic (frequently found both in the sediments and in the water column) and true pelagic (i.e. phytoplankton).

\subsection{Biodiversity metrics and other statistical analyses}

Diatom assemblage diversity was estimated with univariate variables: species richness, Hill's diversity index and the Berger-Parker dominance index (Magurran 1988). Following testing for normality (ShapiroWilks) and equal variance, data were transformed with a log transformation if necessary. Diversity indices, growth forms and biomass were compared between sites and seasons through parametric 2-way ANOVA. All univariate tests were performed with PAST 3.25 (Hammer et al. 2001).

Nonmetric multidimensional scaling (nMDS) was used to better visualise the inter-sample similarities (Clarke 1993) and spatio-temporal patterns of the diatom assemblages. This ordination analysis was made simultaneously with a hierarchical cluster analysis using the SIMPROF test, which provides stopping rules for any a posteriori subdivision of a group of samples (Clarke et al. 2008). An analysis of similarity percentages (SIMPER, Clarke 1993) for each a posteriori group was also performed. SIMPER identifies the species that are most responsible for the observed patterns. All analyses derive from the same similarity matrix, which was constructed using the Bray-Curtis coefficient as sample distance (Bray \& Curtis 1957) and based on the species composition of the assemblages. Abundance data were standardised but not transformed (Ribeiro et al. 2020), and all routines were performed using PRIMER ${ }^{\circledR} 6$.

Sediment chl a concentration and the environmental variables were checked for normality with a Shapiro-Wilks test. Correlations between environmental variables were calculated with a nonparametric Spearman rank order correlation. Ordination analysis was also carried out to assess the relationship of diatom assemblage species composition with environmental parameters. Detrended correspondence analyses were first used to determine gradient lengths, so as to assess whether a linear or unimodal multivariate method should be used. Because the longest length was $2.0(<3.0)$, a linear ordination method was chosen (ter Braak \& Smilauer 2002). After centering the species data and focusing on interspecies correlations, a redundancy analysis (RDA) and an unrestricted Monte Carlo permutation test were applied to test for statistical significance between environmental factors and their effects on species composition variability. All these analyses were performed using CANOCO for Windows 5.0 and included 35 samples, 73 taxa 
and 13 environmental parameters (i.e. irradiance; water and air temperature; salinity; river flow rate; $\mathrm{NO}_{3}{ }^{-}, \mathrm{PO}_{4}{ }^{3-}$ and DSi concentrations; sediment mud and sand fractions; and sediment water, OM and chl a contents). Species abundance data were $\log (x+1)$ transformed.

\section{RESULTS}

\subsection{Environmental parameters}

Particle size analysis showed that the mesohaline mudflat LAV was the muddiest of the sites, with 87.9 to $98 \%$ mud fraction (Table 1). In the polyhaline mudflats (namely, in MEA and BRI), the sediment grain size composition exhibited marked temporal variability, with muddy sediments mostly occurring in spring and early summer (above 90\% mud fraction) and changing to sandy mud later in the year (between 62.3 and $88.4 \%$ mud fraction). Sediment OM content was mostly higher during spring and summer, ranging from 2.2 to $7.0 \%$, and it was positively correlated with the mud fraction (Spearman $\rho=0.74, \mathrm{p}<0.01)$.

The river flow showed large variations throughout the study, with a mean of $1366 \mathrm{~m}^{3} \mathrm{~s}^{-1}$ in January 2012 and $136 \mathrm{~m}^{3} \mathrm{~s}^{-1}$ in July 2011, causing large salinity fluctuations. In the polyhaline mudflats, salinity varied from 2.9 to 30.4 , while in the mesohaline mudflat (LAV), the range was 0.3 to 9.3 (Table 1 ). Water temperature ranged from 8.0 to $20.0^{\circ} \mathrm{C}$ in the polyhaline domain and from 7.7 to $22.4^{\circ} \mathrm{C}$ in the mesohaline domain. All nutrients had higher concentrations during winter and depletions during summer. The river flow was negatively correlated with water temperature $(\rho=-0.91, p<0.01)$ and salinity $(\rho=-0.67, p<$ 0.01 ) but positively correlated with the nutrients $\mathrm{NO}_{3}{ }^{-}(\rho=0.84, \mathrm{p}<0.01), \mathrm{PO}_{4}{ }^{3-}(\rho=0.85, \mathrm{p}<0.01)$ and DSi $(\rho=0.90, p<0.01)$. All these variables were characterised by a marked seasonal cycle typical of a temperate maritime zone, with a high river flow, high nutrient concentrations and low salinity during winter and the opposite pattern during summer.

Table 1. Monthly values (from January 2011 to January 2012) of the environmental parameters at 4 sampling sites in the polyhaline (Méan [MEA], Imperlay [IMP], Brillantes [BRI]) and mesohaline (Lavau [LAV]) domains of the Loire Estuary, France. Mud content and organic matter (OM) content are presented as a percentage (\%) of sediment dry weight. Salinity and water temperature $\left({ }^{\circ} \mathrm{C}\right)$ correspond to the weekly mean before the sampling date (hourly data collected from 2 in situ probes, near MEA and IMP); means \pm SD are given. Air temperature $\left({ }^{\circ} \mathrm{C}\right.$ ) was provided by the Nantes-Bouguenais weather station. Water column nutrient concentrations (nitrate $\left[\mathrm{NO}_{3}{ }^{-}\right]$, phosphate $\left[\mathrm{PO}_{4}{ }^{3-}\right]$, dissolved silica [DSi]) were collected at Sainte-Lucesur-Loire and are monthly means given in $\mu \mathrm{mol} \mathrm{l}^{-1}$. River flow rate (RF), measured in Montjean-Sur-Loire, is in $\mathrm{m}^{3} \mathrm{~s}^{-1}$. Irradiance (IR) is in $\mathrm{J} \mathrm{cm}-2$. No samples were collected in February, April, October or December 2011. nd: data not available

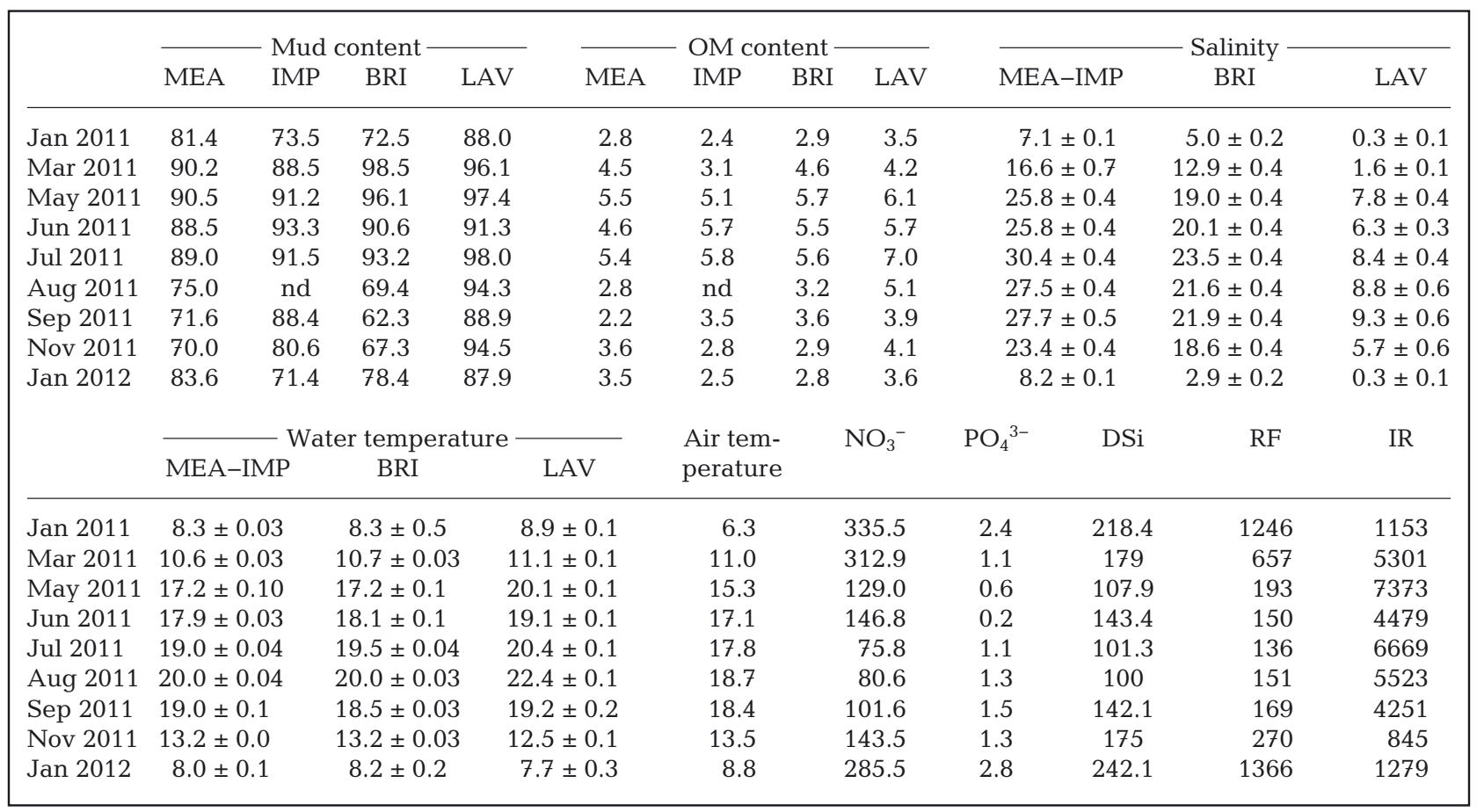




\subsection{Taxonomic composition, assemblage diversity and MPB biomass}

The taxonomic composition of the microphytobenthic biofilms of the Loire Estuary revealed that diatoms dominated the assemblages. This was confirmed by HPLC analyses, which indicated that $\mathrm{chl} C$ and fucoxanthin were the main pigments other than $\mathrm{chl} a$. Chl $b$ was not detected, indicating that there were no euglenophytes or chlorophytes in the sediment samples. Seventy-three diatom taxa were identified (Table 2 and Fig. S1 in the Supplement at www.int-res.com/articles/suppl/a087p061_supp.pdf). Twelve species were common ( $>50 \%$ of samples),

Table 2. Diatom taxa (with codes; $\mathrm{n}=$ 73) found at 4 sampling sites in the polyhaline (Méan [MEA], Imperlay [IMP], Brillantes [BRI]) and mesohaline (Lavau [LAV]) domains of the Loire Estuary. Species occurrence in samples was used to divide species as common (presence in $>50 \%$ of samples), occasional $(10-50 \%)$, rare $(4-10 \%)$ and very rare $(<4 \%)$. For each species, the average relative abundance per site is provided, as well as their growth form (epipelic [EPL], epipsammic [EPS], planktonic [PLA], tychoplanktonic [TYC], others [OTH; periphytic, epilithic, epiphytic, etc.]). Taxa with an average relative abundance higher than $10 \%$ are in bold

\begin{tabular}{|c|c|c|c|c|c|c|}
\hline \multirow[t]{2}{*}{ Taxon } & \multirow[t]{2}{*}{ Code } & \multicolumn{4}{|c|}{ Relative abundance per site (\%) } & \multirow{2}{*}{$\begin{array}{l}\text { Growth } \\
\text { form }\end{array}$} \\
\hline & & MEA & IMP & BRI & LAV & \\
\hline \multicolumn{7}{|l|}{ Common } \\
\hline Aulacoseira subarctica (Müller) Haworth & Asub & 0.3 & 1.4 & 1.4 & 2.5 & PLA \\
\hline Cymatosira belgica Grunow & Cbel & 4.5 & 5.1 & 3.2 & 1.4 & TYC \\
\hline Delphineis minutissima (Hustedt) Simonsen & Delm & 6.2 & 6.0 & 4.5 & 2.0 & TYC \\
\hline Gyrosigma fasciola (Ehrenberg) Griffith \& Henfrey & Gfas & 14.0 & 8.7 & 4.7 & 0.9 & EPL \\
\hline Navicula cf. phyllepta Kützing & Npht & 13.8 & 17.9 & 15.3 & 23.1 & EPL \\
\hline Navicula gregaria Donkin & Ngrg & 8.1 & 7.4 & 8.9 & 10.6 & EPL \\
\hline Navicula spartinetensis Sullivan \& Reimer & Nspr & 10.1 & 4.8 & 11.1 & 7.5 & EPL \\
\hline Rhaphoneis amphiceros (Ehrenberg) Ehrenberg & Raph & 6.7 & 4.0 & 2.7 & 1.9 & TYC \\
\hline Staurosira construens Ehrenberg & Scns & 3.4 & 4.6 & 6.0 & 3.2 & TYC \\
\hline Thalassiosira cf. decipiens (Grunow) Jørgensen & Tdec & 7.8 & 6.8 & 6.4 & 2.2 & TYC \\
\hline Thalassiosira sp. & Thsp & 3.4 & 5.2 & 4.7 & 1.9 & TYC \\
\hline Tryblionella apiculata Gregory & Tapi & 1.2 & 3.0 & 1.2 & 0.1 & EPL \\
\hline \multicolumn{7}{|l|}{ Occasional } \\
\hline Amphora cf. pediculus (Kützing) Grunow ex Schmidt & Aped & 0.2 & 0.4 & 0 & 0 & EPS \\
\hline Amphora sp. & Amsp & 0.8 & 0.9 & 1.8 & 0.1 & EPS \\
\hline Aulacoseira granulata (Ehrenberg) Simonsen & Agra & 0.2 & 0.7 & 0.2 & 0.4 & PLA \\
\hline Brockmanniella brockmanii (Grunow) Hasle, Stosch \& Syvertsen & Bbro & 0 & 0.7 & 0.2 & 0.1 & TYC \\
\hline Cyclotella meneghiniana Kützing & Cmen & 0.5 & 2.5 & 0.1 & 0.4 & TYC \\
\hline Cylindrotheca closterium (Ehrenberg) Reimann \& Lewin & $\mathrm{CyCl}$ & 1.2 & 1.0 & 0 & 0 & EPL \\
\hline Cylindrotheca gracilis Grunow & Cygr & 0.8 & 0.7 & 17.1 & 19.8 & EPL \\
\hline Delphineis surirella (Ehrenberg) Andrews & Dsur & 0.9 & 0.4 & 0 & 0.1 & TYC \\
\hline Diploneis stroemi Hustedt & Dstr & 0.9 & 0.4 & 0.4 & 0.1 & EPL \\
\hline Discostella pseudostelligera (Hustedt) Houk \& Klee & Dpst & 1.1 & 0.2 & 0.4 & 0.3 & PLA \\
\hline Eunotogramma dubium Hustedt & Edub & 0.1 & 0.2 & 0 & 0 & EPS \\
\hline Gyrosigma balticum (Ehrenberg) Rabenhorst & Gbal & 0 & 0 & 0.1 & 2.1 & EPL \\
\hline Gyrosigma limosum Sterrenburg \& Underwood & Glim & 0.3 & 0.5 & 0.2 & 0 & EPL \\
\hline Minidiscus chilensis Rivera & Mchi & 0.7 & 3.0 & 0 & 0 & TYC \\
\hline Navicula cf. cincta (Ehrenberg) Ralfs & Ncin & 0 & 0 & 0 & 3.3 & EPL \\
\hline Navicula microdigitoradiata Lange-Bertalot & Nmic & 0.4 & 0.6 & 0.4 & 3.1 & EPL \\
\hline Navicula salinarum Grunow & Nsal & 2.1 & 0.6 & 0.3 & 0.2 & EPL \\
\hline Nitzschia cf. aequorea Hustedt & Naeq & 1.2 & 4.6 & 1.7 & 0.1 & EPL \\
\hline Nitzschia cf. panduriformis Gregory & Npan & 0.2 & 0.6 & 0.1 & 0.1 & EPL \\
\hline Nitzschia epithemoides Grunow & Nepi & 0 & 0 & 0 & 1.4 & EPL \\
\hline Nitzschia sigma (Kützing) Smith & Nsig & 0.5 & 0.9 & 0.6 & 2.6 & EPL \\
\hline Odontella aurita (Lyngbye) Agardh & Oaur & 0.03 & 0.1 & 0.1 & 0.1 & TYC \\
\hline $\begin{array}{l}\text { Opephora guenter-grassii (Witkowski \& Lange-Bertalot) } \\
\text { Sabbe \& Vyverman }\end{array}$ & Ogue & 1.5 & 0.7 & 1.5 & 0.5 & EPS \\
\hline Paralia sulcata (Ehrenberg) Cleve & Psul & 0.1 & 0.3 & 0 & 0 & TYC \\
\hline Petrodictyon gemma (Ehrenberg) Mann & Pgem & 0.3 & 0.1 & 0.2 & 0.4 & EPL \\
\hline $\begin{array}{l}\text { Plagiogrammopsis vanheurckii (Grunow) Hasle, von Stosch } \\
\text { \& Syvertsen }\end{array}$ & Plva & 2.3 & 0 & 0.6 & 0.2 & TYC \\
\hline Planothidium delicatulum (Kützing) Round \& Bukhtiyarova & Pdel & 0 & 0.7 & 0.3 & 0 & EPS \\
\hline Planothidium frequentissimum (Lange-Bertalot) Lange-Bertalot & Plfr & 0.02 & 0.2 & 0.4 & 0 & EPS \\
\hline Pleurosigma angulatum (Queckett) Smith & Pang & 0.2 & 0.2 & 0.1 & 0.1 & EPL \\
\hline Psammodictyon constrictum (Gregory) Mann & Pcon & 0.3 & 0.8 & 0.2 & 0.1 & EPL \\
\hline Scolioneis tumida (Brébisson ex Kützing) Mann & Scst & 0 & 0 & 0.9 & 1.4 & EPL \\
\hline Sellaphora atomoides (Grunow) Wetzel \& Van de Vijver & Sela & 0.03 & 0 & 0.3 & 0.7 & EPL \\
\hline Staurophora salina (Smith) Mereschkowsky & Ssal & 1.2 & 1.0 & 0 & 2.7 & EPL \\
\hline Thalassiosira cf. proschkinae Makarova & Tpro & 0.4 & 1.0 & 0.3 & 0 & TYC \\
\hline
\end{tabular}


Table 2 (continued)

\begin{tabular}{|c|c|c|c|c|c|c|}
\hline \multirow{2}{*}{ Taxon } & \multirow{2}{*}{ Code } & \multicolumn{4}{|c|}{ Relative abundance per site (\%) } & \multirow{2}{*}{$\begin{array}{l}\text { Growth } \\
\text { form }\end{array}$} \\
\hline & & MEA & IMP & BRI & LAV & \\
\hline \multicolumn{7}{|l|}{ Rare } \\
\hline Achnanthes sp. & Acsp & 0.5 & 0 & 0 & 0 & EPS \\
\hline Cocconeis lineata Ehrenberg & Clin & 0.1 & 0 & 0 & 0 & EPS \\
\hline Cocconeis scutellum Ehrenberg & $\mathrm{Cscu}$ & 0 & 0.5 & 0 & 0 & EPS \\
\hline Cocconeis sp. & Cosp & 0.1 & 0 & 0 & 0 & EPS \\
\hline Cyclotella cf. litoralis Lange \& Syvertsen & Clit & 0 & 0 & 0 & 0.3 & PLA \\
\hline Dimeregramma minor (Gregory) Ralfs in Pritchard & Dmin & 0 & 0 & 0 & 0.2 & EPS \\
\hline Entomoneis paludosa (Smith) Reimer & Epal & 0 & 0 & 0 & 0.3 & EPL \\
\hline Fallacia aequorea (Hustedt) Mann & Faeq & 0.1 & 0 & 0 & 0 & EPS \\
\hline Gedaniella flavovirens (Takano) Li, Witkowski \& Ashworth & Gfla & 0.3 & 0.1 & 0 & 0.2 & EPS \\
\hline Gyrosigma acuminatum (Kützing) Rabenhorst & Gsca & 0 & 0 & 0 & 0.2 & EPL \\
\hline Gyrosigma wansbeckii (Donkin) Cleve & Gwan & 0 & 0 & 0 & 0.2 & EPL \\
\hline Navicula platyventris Meister & Nplt & 0 & 0 & 0.7 & 0 & EPS \\
\hline Navicula ramosissima (Agardh) Cleve & Nram & 0 & 0 & 0.4 & 0.7 & EPL \\
\hline Petroneis humerosa (Brébisson ex Smith) Stickle \& Mann & Phum & 0.2 & 0 & 0 & 0 & EPL \\
\hline Podosira stelligera (Bailey) A. Mann & Pods & 0 & 0.3 & 0 & 0 & TYC \\
\hline Surirella atomus Hustedt & Suat & 0.2 & 0.2 & 0 & 0 & EPL \\
\hline \multicolumn{7}{|l|}{ Very rare } \\
\hline Actinoptychus senarius (Ehrenberg) Ehrenberg & Asen & 0.02 & 0 & 0 & 0 & TYC \\
\hline Cyclotella sp. & Cysp & 0 & 0 & 0.08 & 0 & PLA \\
\hline Diploneis aestuarii Hustedt & Daes & 0 & 0 & 0 & 0.05 & EPL \\
\hline Diploneis didyma (Ehrenberg) Ehrenberg & Ddid & 0 & 0 & 0.03 & 0 & EPL \\
\hline Diploneis sp. & Disp & 0.03 & 0 & 0 & 0 & EPL \\
\hline Geissleria decussis (Østrup) Lange-Bertalot \& Metzeltin & Gdec & 0 & 0 & 0.1 & 0 & EPL \\
\hline Halamphora cf. abuensis (Foged) Levkov & $H a a b$ & 0.5 & 0 & 0 & 0 & EPS \\
\hline Melosira nummuloides Agardh & Mnum & 0 & 0 & 0.1 & 0 & TYC \\
\hline Melosira sp. & Mesp & 0 & 0 & 0 & 0.2 & OTH \\
\hline Plagiotropis seriata (Cleve) Kuntze & Pser & 0.1 & 0 & 0 & 0 & EPL \\
\hline Planothidium polaris (Østrup) Witkowski & Ppol & 0 & 0 & 0.15 & 0 & EPS \\
\hline
\end{tabular}

and of those, 5 were epipelic (Gyrosigma fasciola, Navicula gregaria, N. cf. phyllepta, N. spartinetensis and Tryblionella apiculata), 6 were tychoplanktonic (Cymatosira belgica, Delphineis minutissima, Rhaphoneis amphiceros and Staurosira construens plus 2 taxa belonging to the centric genus Thalassiosira Cleve [i.e. T. cf. decipiens and Thalassiosira sp.]) and 1 was planktonic (Aulacoseira subarctica). Navicula cf. phyllepta had 2 morphotypes that were grouped together during cell counts (Fig. S1) and was the most common and abundant taxon in all mudflats. The occasional species group was the largest, with 34 identified taxa occurring in 10 to $50 \%$ of samples. Sixteen rare and 11 very rare taxa were also found (Table 2).

The relative abundances of the 4 main growth forms were cumulatively added in each sample. The epipelon, epipsammon and tychoplankton exhibited significant spatial and seasonal differences (2-way ANOVA, $\mathrm{p}<0.05)$, but the less abundant phytoplankton did not exhibit differences between sites (2-way ANOVA, $p=0.15)$. In the mesohaline site (LAV), the epipelic fraction consistently dominated the assemblages throughout the study, with relative abundances ranging from 65 to $95 \%$. In BRI, the tychoplanktonic fraction increased to near $50 \%$ in summer. In the downstream polyhaline mudflats, epipelon was less dominant and alternated with tychoplankton as the most abundant fraction (Fig. 2).

Within the epipelic fraction, some of the most common species also showed clear seasonal and spatial variations (Fig. 3). Cylindrotheca gracilis was very abundant in spring and early summer in the 2 mudflats with lower salinity, but it was almost absent in the 2 outermost mudflats (MEA, IMP), hence its occasional frequency. Similarly, G. fasciola showed spatiotemporal variations, with high relative abundance in autumn for the 2 outermost mudflats. Highly abundant everywhere, $N$. cf. phyllepta showed less clear temporal variations, but it had consistently lower numbers during summer and higher abundances during winter in all 4 sites (Fig. 3). Navicula gregaria and $N$. spartinetensis also had less obvious temporal signals.

The spatial and temporal patterns of these common epipelic species played an essential role in the separation of 3 significantly dissimilar groups in the nMDS ordination (Fig. 4, SIMPROF test, $\mathrm{p}<0.05$ ), which are driven by changes in their relative abundance (Table 3, SIMPER analysis). The smallest group (Group I) contains only 2 autumn samples 

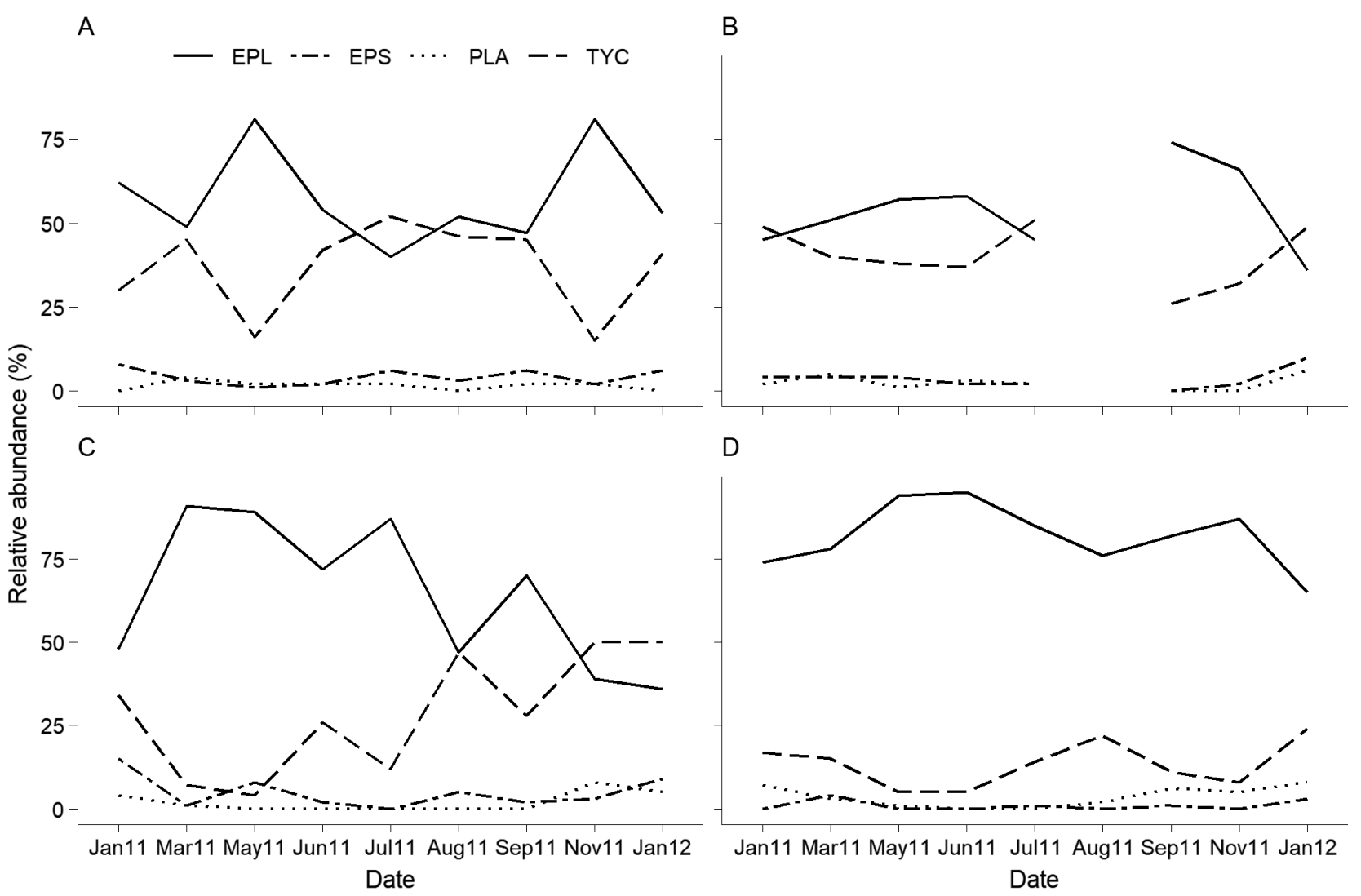

Fig. 2. Relative abundance of the diatom growth forms present at the (A-C) polyhaline (Méan [A], Imperlay [B], Brillantes [C]) and (D) mesohaline (Lavau) mudflats from January 2011 to January 2012. No samples were collected in February, April, October or December 2011. EPL: epipelon; EPS: epipsammon; PLA: plankton; TYC: tychoplankton

dominated by G. fasciola. Group II (Fig. 4, right) is composed exclusively of samples from upstream sites (BRI and LAV), which have typically higher abundances of C. gracilis, but also where the mud fraction was greater (i.e. always above $91 \%$, Table 1). Group III (Fig. 4, left) is the largest group, as it includes samples from the most haline mudflats (MEA and IMP) but also the autumn and winter samples from the other 2 sites (BRI and LAV). These samples were also comparatively sandier (Table 1). The diatom assemblages from Group III had a higher abundance of $N$. cf. phyllepta in common, as well as higher abundances of tychoplanktonic species (e.g. T. cf. decipiens, D. minutissima, C. belgica).

There were significant spatio-temporal variations of species richness and Hill's diversity index, in terms of both site and seasonal differences (2-way ANOVA, $\mathrm{p}<0.05)$. Assemblage diversity tended to decrease from the poly- to the mesohaline mudflats (Table 4). Diversity seasonal variation general trends also differed between mudflats: the 2 most haline mudflats (MEA and IMP) had very high diversities from March to July, which then decreased, in late summer and autumn, to the same range recorded at the other sites (BRI and LAV). During that period, both the epipelic and tychoplanktonic growth form fractions of those assemblages had 2 to 3 times the number of species accounted for in the same fractions in the other samples. The 2 less haline sites did not have a very discernible temporal pattern. There was no statistically significant difference between sites and seasons for the Berger-Parker index (2-way ANOVA, sites: $\mathrm{p}=$ 0.47 , season: $p=0.42$ ), in spite of a pronounced spatial trend, where the mesohaline mudflat (LAV) had a much higher Berger-Parker index mean annual value $(d=0.36$, Table 4$)$ than the polyhaline mudflats. Occasionally, the Berger-Parker index rose in those sites when a single species dominated the assemblages (e.g. G. fasciola in MEA and IMP, C. gracilis in BRI, Fig. 3).

MPB biomass ( $\mathrm{chl}$ a) in the top $2 \mathrm{~mm}$ of sediments showed significant spatial and seasonal differences (2-way ANOVA, p < 0.05), particularly between the mesohaline mudflat which had the highest mean annual MPB biomass and the 3 polyhaline mudflats (Table 4). With regard to temporal variation, biomass 


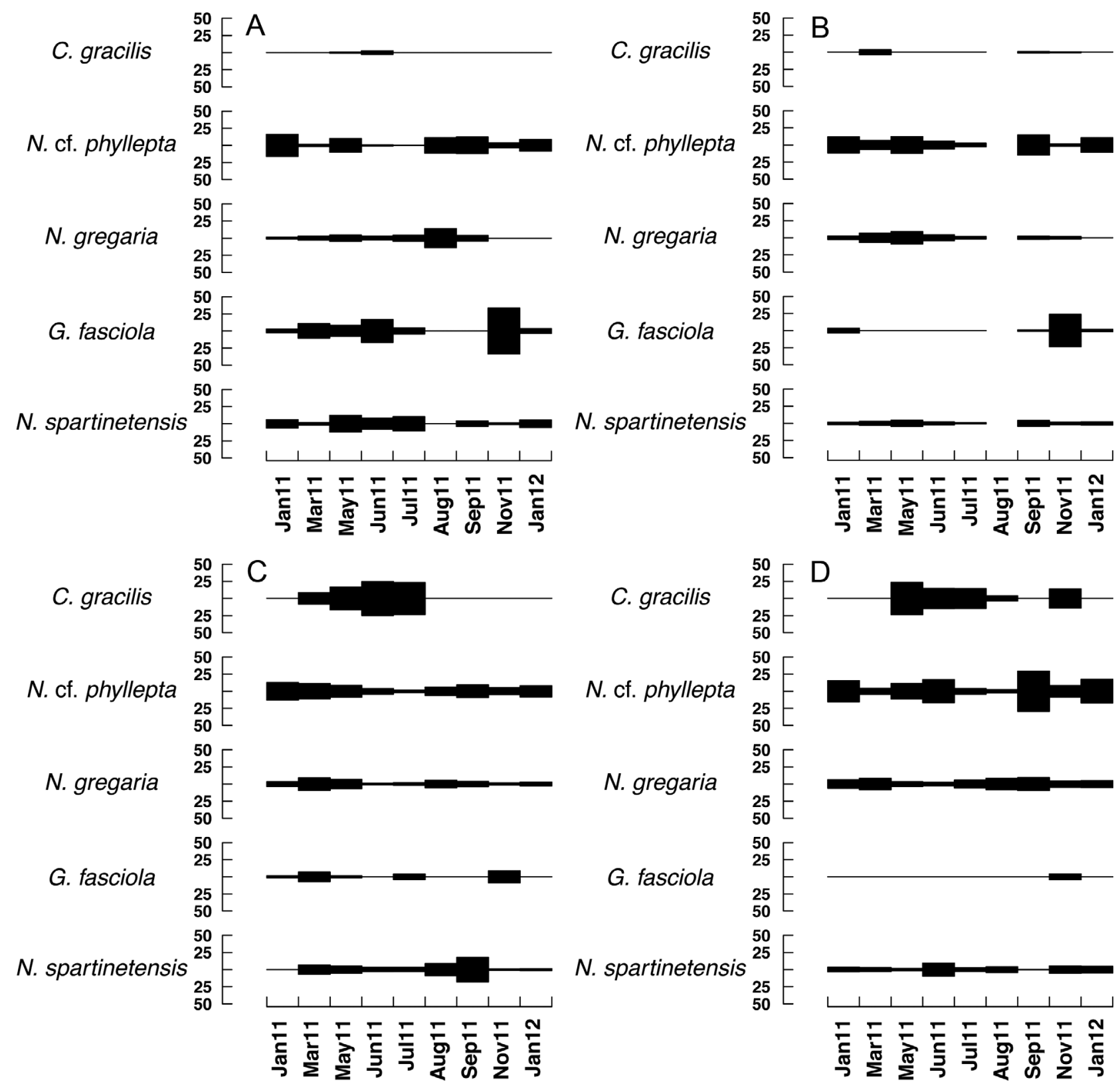

Fig. 3. Relative abundances (\%) of the most abundant epipelic diatom species at the (A-C) polyhaline (Méan [A], Imperlay [B], Brillantes [C]) and (D) mesohaline (Lavau) mudflats from January 2011 to January 2012. Full species names are given in Table 2

was higher during spring and summer and lower during winter, but its peaks varied from site to site. MPB biomass was strongly and positively correlated with the epipelic fraction $(\rho=0.72, p<0.01)$ and negatively correlated with both the tychoplankton $(\rho=$ $-0.69, p<0.01)$ and the epipsammon $(\rho=-0.65, p<$ $0.01)$. Additionally, it was negatively correlated with Hill's diversity index $(\rho=-0.42, p<0.05)$ and positively correlated with the Berger-Parker dominance index $(\rho=0.32, p<0.05)$, when all sites are consid- ered together. MPB biomass was also significantly and positively correlated with the mud fraction $(\rho=$ $0.65, \mathrm{p}<0.01$ ), with higher $\mathrm{chl}$ a content associated with muddier sediments. Contrary to biomass, mud content had a very weak and non-significant relationship with Hill's diversity index $(\rho=-0.06, p=$ $0.72)$. It was also positively correlated with water temperature $(\rho=0.46, p<0.01)$, air temperature $(\rho=$ $0.37, \mathrm{p}<0.05)$ and OM $(\rho=0.60, \mathrm{p}<0.01)$. Conversely, MPB biomass was negatively correlated with 


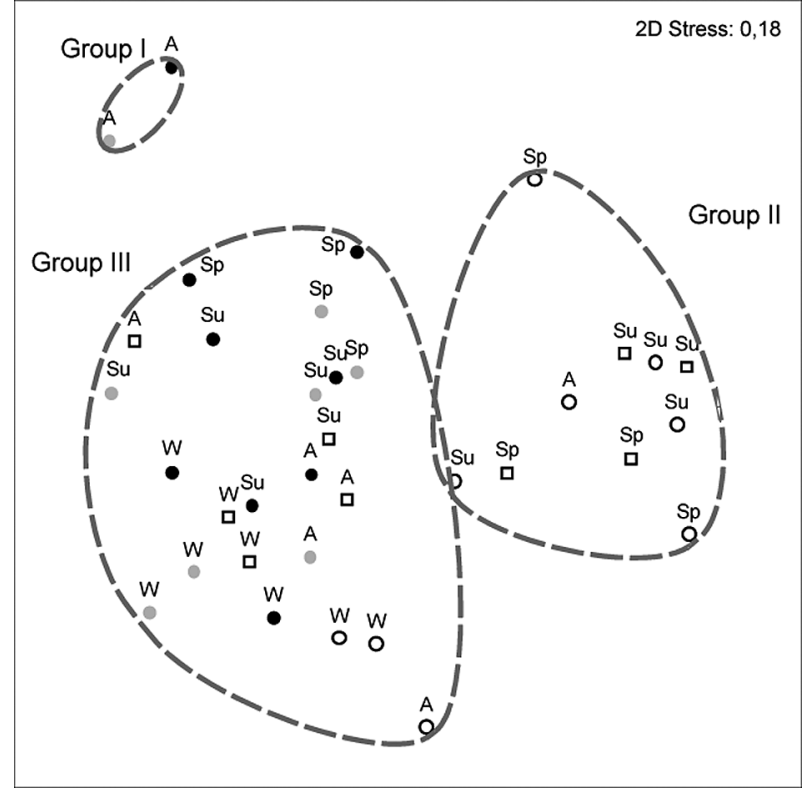

Fig. 4. Nonmetric multidimensional scaling (nMDS) of samples based on species composition found at the 4 Loire mud-

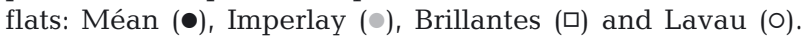
Dashed grey line, at $38 \%$ similarity, represents the overlay clusters not separated (at $\mathrm{p}<0.05$ ) by SIMPROF. W: winter; Sp: spring; Su: summer; A: autumn. Abundance data not transformed

the sand fraction $(\rho=-0.59, p<0.01)$ and nutrient concentrations in the water column $\left(\mathrm{NO}_{3}{ }^{-}: \rho=-0.38\right.$, $\mathrm{p}<0.05$; DSi: $\rho=-0.41, \mathrm{p}<0.05 ; \mathrm{PO}_{4}{ }^{3-}: \rho=-0.33$, $\mathrm{p}<0.05)$.

\subsection{Relationship between MPB community and environmental parameters}

Constrained RDA revealed the relationships of diatom assemblage species composition with the environmental parameters (Fig. 5). The RDA accounted for $49.3 \%$ of the total variance of the data (all canonical axes). Of this, $54.4 \%$ was explained by the first 2 axes, which were significant $(p<$ 0.001 ). RDA axis 1 explained $32.3 \%$ of this variation, achieving a $\rho=0.95$ correlation with the environmental dataset, in particular with $\mathrm{OM}(\rho=0.69)$, mud $(\rho=0.63)$ and sand $(\rho=-0.64)$. It chiefly presented a gradient of sediment texture from sandy mud to mud. RDA axis 2 explained $18.0 \%$ and was correlated with the environmental dataset $(\rho=$ $0.95)$, with salinity $(\rho=0.64)$ and $\mathrm{PO}_{4}{ }^{3-}$ concentrations $(\rho=-0.69)$ as the main explanatory variables. RDA axis 2 mostly revealed the seasonal effect of river flow along the studied sites, by decreasing salinity and raising the nutrient loads during winter. Given the very high correlation between water temperature and air temperature $(\rho=0.96)$, only 11 environmental variables are displayed in the biplot (Fig. 5). The arrangement of species along the first gradient in the upper right quadrant of the plot was positively related to the mud fraction, $\mathrm{OM}$ and temperature and negatively related to the sand fraction. The common epipelic species C. gracilis, N. gregaria and $N$. spartinetensis had higher abundances in higher muddy sediment during warmer seasons (spring or summer). Conversely, the most abundant epipsammic species, Opephora guenter-grassii, presented a close relation with the sand fraction. Species distributed in the lower left quadrant of the plot were positively linked to river flow and nutrients (DSi, $\mathrm{NO}_{3}{ }^{-}$and $\mathrm{PO}_{4}{ }^{3-}$ ). The most common tychoplanktonic species, C. belgica, D. minutissima, $R$. amphiceros and Thalassiosira sp., were all grouped together and partly related to the environmental variables typical of winter conditions. Many species did not show a relation with sediment texture but were related to salinity. Navicula phyllepta had a singular positioning in the RDA space.

Table 3. Summary of SIMPER results for the 3 overlay clusters shown in Fig. 4: average abundance (\%) of typifying species in each group and their contribution (\%) to withingroup similarity. nd: no data

\begin{tabular}{|lcc|}
\hline Species & Abundance & Contribution \\
\hline Group I (avg. similarity: 65.4 \%) & & \\
Gyrosigma fasciola & 56.6 & 72.7 \\
Navicula spartinetensis & 4.4 & 6.0 \\
Navicula cf. phyllepta & 5.3 & 5.2 \\
Thalassiosira cf. decipiens & 4.5 & 5.2 \\
Rhaphoneis amphiceros & 4.5 & 3.9 \\
Thalassiosira sp. & 5.7 & 3.9 \\
Staurosira construens & 2.3 & 3.0 \\
Group II (avg. similarity: 55 \%) & & \\
Cylindrotheca gracilis & 33.2 & 40.7 \\
Navicula cf. phyllepta & 13.5 & 16.8 \\
Navicula gregaria & 10.8 & 15.3 \\
Navicula spartinetensis & 9.4 & 12.3 \\
Thalassiosira cf. decipiens & 3.0 & 2.7 \\
Staurosira construens & 2.4 & 2.0 \\
Others & $\mathrm{nd}$ & 9.1 \\
Group III (avg. similarity: 49.3\%) & \\
Navicula cf. phyllepta & 20.3 & 26.4 \\
Thalassiosira cf. decipiens & 7.1 & 9.4 \\
Navicula gregaria & 8.5 & 9.4 \\
Delphineis minutissima & 6.1 & 8.5 \\
Navicula spartinetensis & 8.4 & 8.0 \\
Cymatosira belgica & 4.7 & 7.0 \\
Others & $\mathrm{nd}$ & 30.5 \\
& & \\
\hline
\end{tabular}


Table 4. Monthly values of chl a concentration, measured in the top $2 \mathrm{~mm}$ of sediment (mean $\pm \mathrm{SD} ; \mathrm{n}=3$ ), and of the BergerParker dominance index and diversity indices (Hill's N1 diversity index, species richness) at 4 mudflats of the Loire Estuary, in the polyhaline (Méan [MEA], Imperlay [IMP], Brillantes [BRI]) and mesohaline (Lavau [LAV]) domains. nd: no data

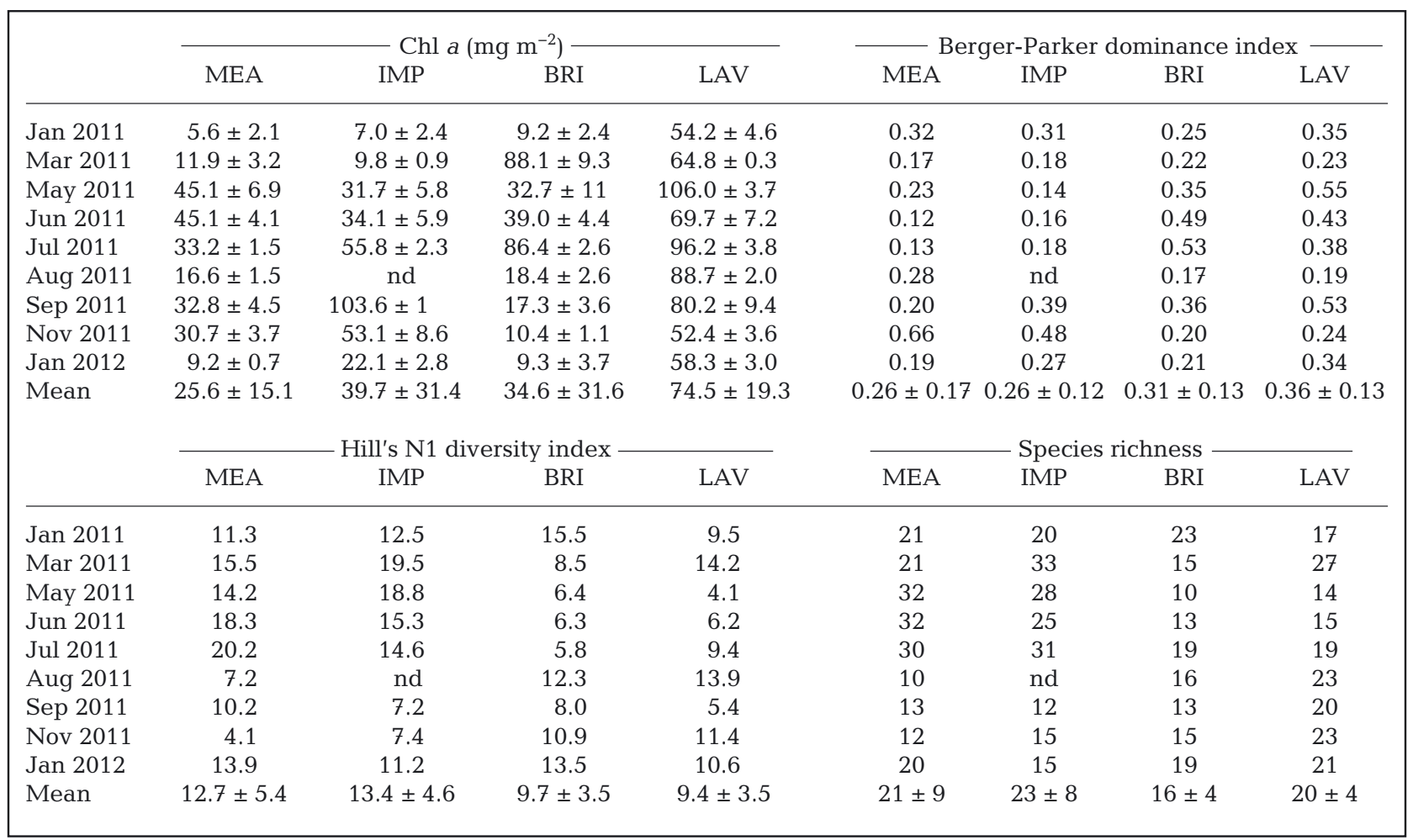

\section{DISCUSSION}

\subsection{Comparison with other European estuaries}

Diatoms dominated the MPB assemblages throughout the 13 mo study, as both microscopic observations and HPLC pigment analysis did not detect any other microalgal groups. The Loire Estuary mudflat diatom assemblages shared many similarities with the nearby Bourgneuf Bay mudflat assemblages (Méléder et al. 2007), as well as with other European mesotidal (e.g. Peletier 1996, Ribeiro et al. 2003) and macrotidal (e.g. Underwood 1994, Thornton et al. 2002, Sahan et al. 2007) estuaries. MPB assemblages were typically dominated by medium-sized (i.e. 250 to $1000 \mathrm{\mu m}^{3}$ ) motile diatoms, mostly belonging to the genus Navicula Bory, which is similar to other European intertidal mudflats (Sabbe 1997, Ribeiro 2010, Scholz \& Liebezeit 2012). However, they also presented important structural differences that should be highlighted.

The most noticeable feature of the Loire Estuary assemblages was the contribution of the tychoplanktonic fraction in the polyhaline sites, which became the dominant growth form on several occasions (Fig. 2).
Tychoplankton dominance in mudflat assemblages is not exclusive of the Loire Estuary, having been reported in other macrotidal areas, e.g. the Bay of Fundy, eastern Canada (Trites et al. 2005), or in hyper-tidal and macrotidal estuaries, where tychoplanktonic occasional dominance has also been reported (Juggins 1992, Underwood 1994, Thornton et al. 2002). Sabbe (1997) described a similar tychoplanktonic assemblage in polyhaline mudflat sediments from the macrotidal Westerschelde Estuary, which was also mainly composed of Cymatosira belgica, Delphineis minutissima, Rhaphoneis amphiceros and Thalassiosira decipiens. The latter species was the most common Thalassiosira species in silty stations throughout that Belgian-Dutch estuary (Muylaert \& Sabbe 1996). Notably, T. cf. decipiens cell counts in the Loire Estuary probably included the morphologically similar T. angulata (Gregory) Hasle, a true planktonic marine species that can also occur in meso- and macrotidal estuaries (Muylaert \& Sabbe 1996, Ribeiro 2010). Furthermore, in their phytoplankton study in European estuary maximum turbidity zones, Muylaert \& Sabbe (1999) noticed that tychoplanktonic assemblages represented $20 \%$ of the total cell number in the polyhaline water column 


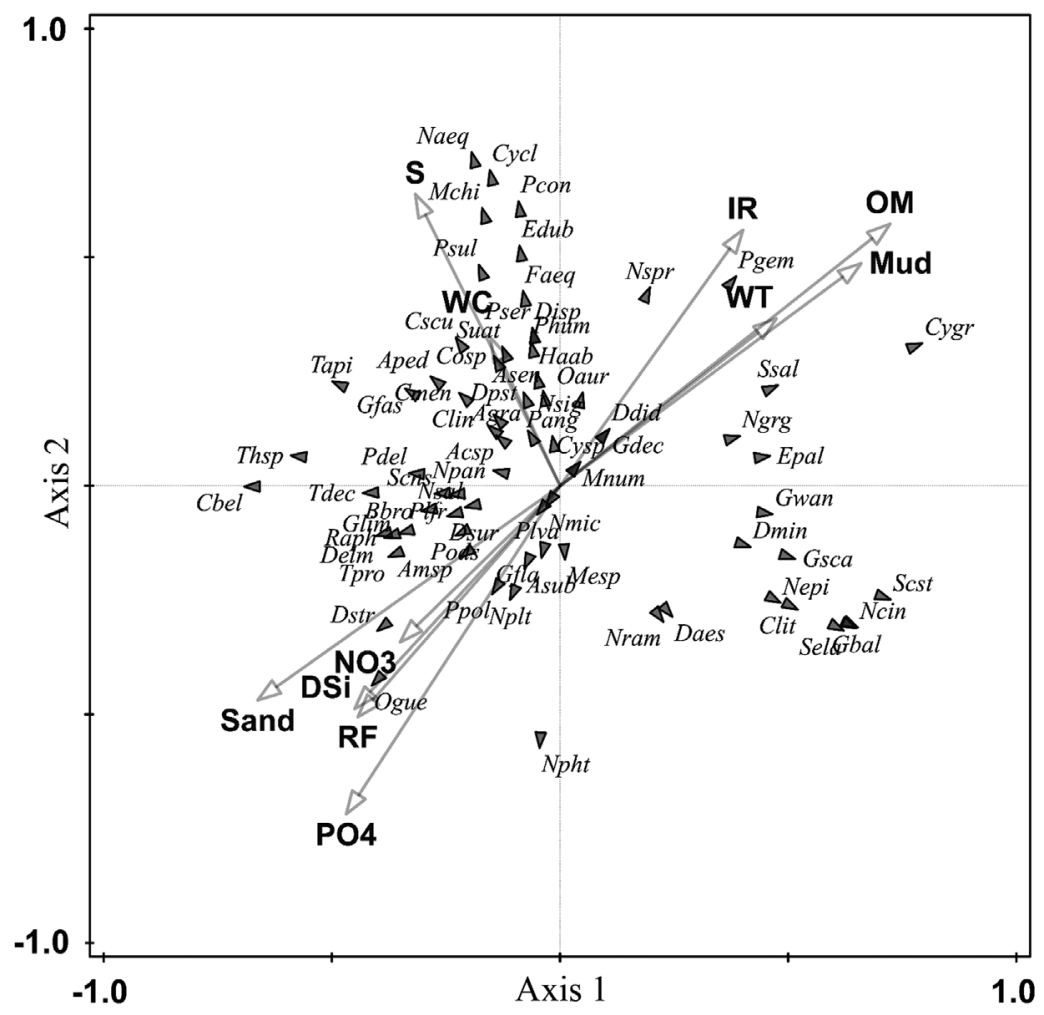

Fig. 5. Redundancy analysis based on log-transformed species relative abundance. Solid arrowheads and italic labels indicate species; lines with empty arrowheads and bold labels indicate environmental factors. IR: irradiance; RF: river flow rate; WT: water temperature; S: salinity; WC: sediment water content; OM: sediment organic matter content; Mud: mud fraction (\%); Sand: sand fraction (\%); NO3: nitrate $\left(\mathrm{NO}_{3}{ }^{-}\right)_{i} \mathrm{PO} 4$ : phosphate $\left(\mathrm{PO}_{4}{ }^{3-}\right)_{i} \mathrm{DSi}$ : dissolved silica. Diatom species codes are given in Table 2

of the macrotidal Schelde Estuary and $9 \%$ in the poly- and mesohaline sections of the mesotidal Elbe Estuary (Germany). Therefore, MPB tychoplanktonic fractions in both the Loire and Westerschelde estuaries are characteristically high and composed of the same set of tychoplanktonic species, with comparable spatial distribution patterns.

The existence of an important and even dominant tychoplanktonic fraction in intertidal diatom assemblages could be considered a distinctive feature of estuarine macrotidal benthic environments. This predominance does not seem to occur in either the French Atlantic coastal areas, where tychoplankton appears sporadically but is never dominant (Méléder et al. 2007, Hernández Fariñas et al. 2017), or mesotidal estuaries (e.g. Admiraal \& Peletier 1980a, Ribeiro et al. 2013). However, further mesotidal studies are needed to confirm if this spatial pattern is really a macrotidal estuarine feature. Mudflat MPB assemblages have been traditionally sampled with the lens tissue method (Eaton \& Moss 1966), which selectively collects the motile epipelic fraction, possibly resulting in a tychoplankton underestimation in previous studies (e.g. Ribeiro et al. 2003). Tychoplanktonic diatoms seem to share the same physiological photoprotective traits as raphid epipelic motile diatoms (Barnett et al. 2015) and are particularly well adapted to low-light environments (Jesus et al. 2009, Blommaert et al. 2017). This natural low-light acclimation seems particularly useful in macrotidal estuaries, which have very turbid waters, and may partly explain their success in the Loire Estuary polyhaline reaches. By moving from the pelagic to the benthic environment, they prolong their stay in estuarine intertidal areas, where nutrient conditions are favourable (Sabbe et al. 2010), while using the tidal resuspension cycles as a dispersion mechanism (Redzuan \& Underwood 2020). Contrary to the epipelon, tychoplanktonic diatoms cannot vertically migrate to the sediment surface during low tides (Consalvey et al. 2004). Their dominance of mudflat MPB assemblages may have obvious implications on intertidal biofilm ecophysiology, daily primary productivity patterns (Underwood et al. 2005) and remote sensing biomass estimation in macrotidal estuarine areas (Benyoucef et al. 2014).

Regarding the MPB epipelic fraction, there may also be differences between the Loire epipelic assemblages and those described for other European estuaries. However, some of the taxonomic differences warrant further studies, as morphologically similar species may be conspecific. One example is Cylindrotheca signata and C. gracilis, the former reported as a common species in mudflats in the Severn Estuary, UK (Underwood 1994) and the latter dominating the upstream Loire assemblages in this study. Likewise, N. flanatica is one of most abundant epipelic species in the Westerschelde (Sabbe 1997, Sahan et al. 2007) and is morphologically very similar to N. spartinetensis (Witkowski et al. 2012), a common species in the Loire (this study) and Bourgneuf Bay (Méléder et al. 2007). Multivariate analysis showed large differences in MPB assemblage structure between 3 UK estuaries in a study that had the benefit of a standardised sampling methodology and taxonomy 
(Underwood \& Barnett 2006). A similar study, comparing several macro- and mesotidal European estuaries, could clarify these large-scale spatial patterns but would necessarily need a previous taxonomic harmonisation.

\subsection{Spatio-temporal patterns}

Diatom assemblages had significant spatial and seasonal differences in terms of their growth form composition, with the epipelon dominating spring assemblages and decreasing in abundance from the mesohaline to the polyhaline sites. However, at a species level, sample clustering in 3 significantly dissimilar groups (nMDS, Fig. 4) indicated that spatial and temporal patterns could not be completely decoupled. The largest group (Group III) consisted of samples from the 4 mudflats, while Group II included only spring and summer samples from 2 upstream sites (BRI and LAV). These patterns were mainly driven by changes in the relative abundance of the 10 most common species (Tables $2 \& 3$, SIMPER analysis). Dissimilarities may partially be attributed to the spatial distribution of epipelic and tychoplanktonic species, but the seasonal progression of abundance peaks by the most common epipelic diatoms also played a major role (Fig. 3). For example, C. gracilis was a typical spring-summer species but was only abundant in the 2 upstream sites. Likewise, Gyrosigma fasciola mainly occurred in the polyhaline sites and had a distinct autumn bloom. These synchronous species-specific seasonal peaks in abundance of epipelic species are a typical feature of temperate intertidal mudflat assemblages (Aleem 1950, Hendey 1964) and were similar to those described for other European coastal environments (see Table S1 and references therein). In upstream sites, there was a difference between spring-summer and autumnwinter assemblage structure, similar to what was observed at the Marennes-Oléron mudflats (Haubois et al. 2005). The separation in 2 seasonal groups is a common feature to several European mudflat assemblages, but the main difference may also be between winter-spring and summer-autumn mudflat assemblages (e.g. Sahan et al. 2007, Ribeiro et al. 2013).

The RDA suggests that diatom community shifts were mainly influenced by sediment texture and salinity, which are known to play an important role in structuring estuarine diatom assemblages (Sabbe \& Vyverman 1991, Forster et al. 2006, Rovira et al. 2012, Ribeiro et al. 2013). In our study, these 2 variables had strong seasonal variations, which affected the expected spatial gradient, from the mesohaline LAV site to the downstream 3 polyhaline mudflats. All sites were mostly muddy, but polyhaline sites showed slight seasonal changes in sediment composition (e.g. lower mud content in winter) that induced minor shifts in assemblage structure. Namely, the epipsammic species Opephora guenter-grassii, which is known to be unaffected by silty sediments (Sabbe \& Vyverman 1995), was positively correlated with sand content and occurred mostly in winter. Most epipelic species were positioned on the RDA left side of axis 1 (Fig. 5), which reflects their dominance in siltier sediments, while their placement along axis 2 highlights different salinity preferences and speciesspecific seasonality. The effects of salinity and nutrient concentrations on the distribution of estuarine benthic diatoms should be considered together (Underwood et al. 1998, Underwood \& Provot 2000). In our study, without knowing the differences in nutrient load between sampling sites (Table 1), it is difficult to estimate the combined effect of nutrients and salinity on species spatial distribution, but their effect on species turnover throughout the year cannot be discarded. Other variables with clear seasonal patterns that affect the estuary as a whole, such as temperature (Vieira et al. 2013), day length and irradiance (Sabbe 1993, Sahan et al. 2007), are known to have concomitant effects with salinity that may enhance or impair the growth and competitive ability of the different dominant species, causing the community structure to change continuously (Admiraal \& Peletier 1980b). Furthermore, the seasonal succession of ciliates and other meiofaunal communities may also influence the temporal succession of epipelic species, through shifts in interspecific interactions between diatoms (e.g. competition) caused by selective grazing (Hamels et al. 1998, D'Hondt et al. 2018).

\subsection{Biomass and diversity}

MPB biomass ( $\mathrm{chl} a$ ) found in the Loire mudflats varied between 6 and $106 \mathrm{mg} \mathrm{m}^{-2}$, which is within the concentration range reported for other estuaries (e.g. Underwood \& Kromkamp 1999, Thornton et al. 2002, Forster et al. 2006). There was a clear difference in MPB biomass spatial distribution, with the mesohaline site characterised by higher average chl a content than the polyhaline sites - a spatial pattern consistent with previous works (e.g. Benyoucef et al. 2014). High MPB biomass temporal variability within the same estuary is a common feature in tem- 
perate estuaries (Underwood \& Kromkamp 1999), with biomass dependent on local environmental conditions, such as erosion and deposition events. That seems to also have been the case in the Loire Estuary. In each site, biomass peaked at different times, from early spring to autumn, albeit all sharing a clear decrease in winter. Tidal height, an important factor in determining site-specific temporal patterns (e.g. Admiraal \& Peletier 1980b, Jesus et al. 2009), seemed to play a minor role, as all 4 sites have similar tidal positions. Therefore, unmeasured environmental or biotic parameters, such as grazing pressure (Sahan et al. 2007) or bioturbation (D'Hondt et al. 2018), were most likely behind the biomass seasonal patterns observed in each site.

Diatom assemblage diversity also had a clear spatial pattern, with the 2 downstream sites having higher diversities than the 2 less haline upstream sites (Table 3). Both species richness and Hill's diversity index were within the reported range for estuarine mudflat assemblages (Table S2 and references therein). The epipelon-dominated assemblages in the upstream mudflats did not show an obvious seasonal diversity pattern, consistent with previous studies (e.g. Ribeiro 2010). Mudflat diatom assemblages can be species rich but are often dominated by a small set of epipelic species (e.g. Colijn \& Dijkema 1981, Witkowski et al. 2004) and subject to interspecific competition that lowers diversity (de Jong \& Admiraal 1984). Contrastingly, the 2 downstream mudflats showed unusually high diversities from March to July 2011 before returning to similar levels observed in the 2 upstream sites (Table 3 ). This diversity seemed to be the result of the co-existence of 2 growth forms (epipelon and tychoplankton) in the downstream sites. MPB assemblages with different growth forms (e.g. epipsammon and epipelon in sandy muddy sediments) are known to have higher diversities (Paterson \& Hagerthey 2001, Ribeiro et al. 2013), possibly through niche differentiation (Virta et al. 2019).

Therefore, observed MPB biomass and diversity patterns confirmed a pattern already reported for the Westerschelde intertidal flats (Forster et al. 2006), where biomass is inversely related to biofilm diversity (i.e. higher biomass in lower-diversity assemblages). MPB biomass was also positively correlated with both mud content and epipelon content. Upstream spring assemblages seemed to show that when the right environmental conditions are met, a small group of motile epipelic species quickly dominates the site through inter-specific competition (Admiraal \& Peletier 1980a), niche complementary effects (Vanelslander et al. 2009) and/or selective grazing (Hagerthey et al. 2002, D'Hondt et al. 2018), which leads to rapid biomass accumulation and low species diversity (Sahan et al. 2007). Conversely, while mud content was positively correlated with MPB biomass, it had no significant impact on MPB diversity. This seems counter-intuitive, as a negative correlation would be expected. However, the diversity increases in the downstream sites induced by the tychoplanktonic fraction was not accompanied by a decrease in mud content. Therefore, slight changes in sediment texture, even if causing minor variations in assemblage structure, did not change overall diversity of these mudflat assemblages.

\section{CONCLUSIONS}

Mudflat MPB assemblages were mostly dominated by epipelic diatoms, but there was a significant contribution of tychoplankton, particularly in the polyhaline reaches of the Loire Estuary. As hypothesised, the turnover in species composition along the salinity gradient did cause shifts in growth form composition and diversity. Likewise, the strong species seasonal dynamics was not translated into clear seasonal variations in diversity in the epipelon-dominated assemblages. However, the assemblages in the 2 downstream sites did show temporal variability in diversity and were co-dominated by the epipelic and tychoplanktonic fractions. Biomass was positively correlated with the epipelon and negatively correlated with the epipsammon and tychoplankton. It was also negatively correlated with diversity, confirming previous reports where low-diversity epipelic biofilms accumulated more biomass (Forster et al. 2006). Growth form analysis highlighted the hidden role that tychoplankton could be playing in MPB assemblages. These higher abundances may well be a distinctive feature of macrotidal environments in temperate areas, and the presence of a non-motile but relevant diatom faction, colonizing muddy intertidal sediments, raises many questions about the functioning of these biofilms. Further studies, using nonselective methods that sample all growth forms present in the biofilms, in different tidal estuaries and coastal areas are warranted.

Acknowledgements. This study was supported by a grant by the L'Agence Française pour la Biodiversité, AFB grant number 180906 - Convention Microphytobenthos Phase II, and had the financial support of the Fundação para a Ciência e a Tecnologia (FCT) through UID/MAR/04292/2020. This study was also conducted as part of the PhD grant of 
I.B. supported by the Ministère Français de la Recherche et de l'Enseignement Supérieur and awarded by the Fédération de Recherche IUML FR-CNRS of the University of Nantes. B.J. was partially funded by the BIO-Tide project, funded through the 2015-2016 BiodivERsA COFUND call for research proposals, with the national funders BelSPO, FWO, ANR and SNSF. The authors also thank the 3 reviewers for helpful comments that improved the manuscript.

\section{LITERATURE CITED}

Admiraal W, Peletier H (1980a) Distribution of diatom species on an estuarine mud flat and experimental analysis of the selective effect of stress. J Exp Mar Biol Ecol 46: $157-175$

Admiraal W, Peletier H (1980b) Influence of seasonal variations of temperature and light on the growth rate of cultures and natural populations of intertidal diatoms. Mar Ecol Prog Ser 2:35-43

Aleem AA (1950) The diatom community inhabiting the mud-flats at Whitstable. New Phytol 49:174-188

Baize D (2018) Guide des analyses en pédologie. 3ème édition revue et augmentée. Éditions Quae, Versailles

Barillé-Boyer AL, Barillé L, Massé H, Razet D, Héral M (2003) Correction for particulate organic matter as estimated by loss on ignition in estuarine ecosystems. Estuar Coast Shelf Sci 58:147-153

Barnett A, Méléder V, Blommaert L, Lepetit B and others (2015) Growth form defines physiological photoprotective capacity in intertidal benthic diatoms. ISME J 9: 32-45

Benyoucef I, Blandin E, Lerouxel A, Jesus B and others (2014) Microphytobenthos interannual variations in a north-European estuary (Loire estuary, France) detected by visible-infrared multispectral remote sensing. Estuar Coast Shelf Sci 136:43-52

Blanchard G, Chrétiennot-Dinet MJ, Dinet A, Robert JM (1988) Méthode simplifiée pour l'extraction du microphytobenthos des sédiments marins par le gel de silice Ludox. Comptes Rendus de l'Académie des Sciences 307:569-576

Blanchard G, Agion T, Guarini JM, Herlory O, Richard P (2006) Analysis of the short-term dynamics of microphytobenthos biomass on intertidal mudflats. In: Kromkamp JC, de Brouwer JFC, Blanchard GF, Forster RM, Créach V (eds) Functioning of microphytobenthos in estuaries. Royal Netherlands Academy of Arts and Sciences, Amsterdam, p 85-97

Blommaert L, Huysman MJJ, Vyverman W, Lavaud J, Sabbe K (2017) Contrasting NPQ dynamics and xanthophyll cycling in a motile and a non-motile intertidal benthic diatom. Limnol Oceanogr 62:1466-1479

Bray JR, Curtis JT (1957) An ordination of the upland forest communities of southern Wisconsin. Ecol Monogr 27: 325-349

Clarke KR (1993) Non-parametric multivariate analyses of changes in community structure. Aust J Ecol 18:117-143

Clarke KR, Somerfield PJ, Gorley RN (2008) Testing of null hypotheses in exploratory community analyses: similarity profiles and biota-environment linkage. J Exp Mar Biol Ecol 366:56-69

Colijn F, Dijkema KS (1981) Species composition of benthic diatoms and distribution of chlorophyll $a$ on an intertidal flat in the Dutch Wadden Sea. Mar Ecol Prog Ser 4:9-21
Consalvey M, Paterson DM, Underwood GJC (2004) The ups and downs of life in a benthic biofilm: migration of benthic diatoms. Diatom Res 19:181-202

* D'Hondt AS, Stock W, Blommaert L, Moens T, Sabbe K (2018) Nematodes stimulate biomass accumulation in a multispecies diatom biofilm. Mar Environ Res 140:78-89

* de Jong L, Admiraal W (1984) Competition between three estuarine benthic diatom species in mixed cultures. Mar Ecol Prog Ser 18:269-275

* de Jonge VN, van Beusekom JFF (1992) Contribution of resuspended microphytobenthos to total phytoplankton in the Ems estuary and its possible role for grazers. Neth J Sea Res 30:91-105

*Du GY, Chung IK (2009) Estimating areal production of intertidal microphytobenthos based on spatio-temporal community dynamics and laboratory measurements. Ocean Sci J 44:189-197

* Du G, Yan H, Dupuy C (2017) Microphytobenthos as an indicator of environmental quality status in intertidal flats: case study of coastal ecosystem in Pertuis Charentais, France. Estuar Coast Shelf Sci 196:217-226

*Eaton JW, Moss B (1966) The estimation of numbers and pigment content in epipelic algal populations. Limnol Oceanogr 11:584-595

*Etcheber H, Taillez A, Abril G, Garnier J, Servais P, Moatar F, Commarieu MV (2007) Particulate organic carbon in the estuarine turbidity maxima of the Gironde, Loire and Seine estuaries: origin and lability. Hydrobiologia 588: 245-259

Ford RB, Honeywill C (2002) Grazing on intertidal microphytobenthos by macrofauna: Is pheophorbide a a useful marker? Mar Ecol Prog Ser 229:33-42

Forster RM, Créach V, Sabbe K, Vyverman W, Stal LJ (2006) Biodiversity-ecosystem function relationship in microphytobenthic diatoms of the Westerschelde estuary. Mar Ecol Prog Ser 311:191-201

*Gameiro C, Zwolinski J, Brotas V (2011) Light control on phytoplankton production in a shallow and turbid estuarine system. Hydrobiologia 669:249-263

*Hagerthey SE, Defew EC, Paterson DM (2002) Influence of Corophium volutator and Hydrobia ulvae on intertidal benthic diatom assemblages under different nutrient and temperature regimes. Mar Ecol Prog Ser 245:47-59

*Hamels I, Sabbe K, Muylaert K, Barranguet C, Lucas C, Herman P, Vyverman W (1998) Organisation of microbenthic communities in intertidal estuarine flats, a case study from the Molenplaat (Westerschelde estuary, The Netherlands). Eur J Protistol 34:308-320

Hammer $\varnothing$, Harper DAT, Ryan PD (2001) PAST: paleontological statistics software package for education and data analysis. Palaeontol Electronica 4:4

Haubois AG, Sylvestre F, Guarini JM, Richard P, Blanchard GF (2005) Spatio-temporal structure of the epipelic diatom assemblage from an intertidal mudflat in MarennesOléron Bay, France. Estuar Coast Shelf Sci 64:385-394

Hendey NI (1964) An introductory account of the smaller algae of British coastal waters. V. Bacillariophyceae (diatoms). Her Majesty's Stationery Office, London

* Hernández Fariñas T, Ribeiro L, Soudant D, Belin C, Bacher C, Lampert L, Barillé L (2017) Contribution of benthic microalgae to the temporal variation in phytoplankton assemblages in a macrotidal system. J Phycol 53: 1020-1034

Hope JA, Paterson DM, Thrush SF (2020) The role of microphytobenthos in soft-sediment ecological networks and 
their contribution to the delivery of multiple ecosystem services. J Ecol 108:815-830

Jesus B, Mendes CR, Brotas V, Paterson DM (2006) Effect of sediment type on microphytobenthos vertical distribution: modelling the productive biomass and improving ground truth measurements. J Exp Mar Biol Ecol 332:60-74

Jesus B, Brotas V, Ribeiro L, Mendes CR, Cartaxana P, Paterson DM (2009) Adaptations of microphytobenthos assemblages to sediment type and tidal position. Cont Shelf Res 29:1624-1634

Juggins S (1992) Diatoms in the Thames estuary, England: ecology, palaeoecology, and salinity transfer function. J. Cramer, Berlin

MacIntyre HL, Geider RJ, Miller DC (1996) Microphytobenthos: the ecological role of the 'secret garden' of unvegetated, shallow-water marine habitats. I. Distribution, abundance and primary production. Estuaries 19:186-201

Magurran AE (1988) Ecological diversity and its measurement. Springer, Dordrecht

Marchand J, Elie P (1983) Contribution à l'étude des peuplements benthiques de l'estuaire de la Loire: examens particuliers de la dynamique et la production de la macrofaune benthique, la dynamique des biomasses microphytobenthiques. Rapport Final du Comité Scientifique pour l'Environnement de l'Estuaire de la Loire pour le Ministère de l'environnement, Ministère de la mer, Nantes

McIntire CD, Moore WW (1977) Marine littoral diatoms: ecological considerations. In: Werner D (ed) The biology of diatoms. Blackwell Scientific, Oxford

McLusky DS, Elliott M (2004) The estuarine ecosystem: ecology, threats and management. Oxford University Press, Oxford

Méléder V (2003) Étude de la structure des peuplements intertidaux du microphytobenthos. Apport de la Télédétection Visible-infrarouge. PhD dissertation, Université de Nantes

* Méléder V, Barillé L, Rincé Y, Morançais M, Rosa P, Gaudin P (2005) Spatio-temporal changes in microphytobenthos structure analysed by pigment composition in a macrotidal flat (Bourgneuf Bay, France). Mar Ecol Prog Ser 297: 83-99

Méléder V, Rincé Y, Barillé L, Gaudin P, Rosa P (2007) Spatiotemporal changes in microphytobenthos assemblages in a macrotidal flat (Bourgneuf Bay, France). J Phycol 43: 1177-1190

Moatar F, Meybeck M (2005) Compared performances of different algorithms for estimating annual nutrient loads discharged by the eutrophic River Loire. Hydrol Processes 19:429-444

Monbet Y (1992) Control of phytoplankton biomass in estuaries: a comparative analysis of microtidal and macrotidal estuaries. Estuaries 15:563-571

Muylaert K, Sabbe K (1996) The diatom genus Thalassiosira (Bacillariophyta) in the estuaries of the Schelde (Belgium/ The Netherlands) and the Elbe (Germany). Bot Mar 39: 103-115

Muylaert K, Sabbe K (1999) Spring phytoplankton assemblages in and around the maximum turbidity zone of the estuaries of the Elbe (Germany), the Schelde (Belgium/ The Netherlands) and the Gironde (France). J Mar Syst 22:133-149

Nedwell DB, Underwood GJC, McGenity TJ, Whitby C, Dumbrell AJ (2016) The Colne estuary: a long-term microbial ecology observatory. Adv Ecol Res 55:227-281

Oppenheim DR (1991) Seasonal changes in epipelic diatoms along an intertidal shore, Berrow flats, Somerset. J Mar Biol Assoc UK 71:579-596

* Park J, Kwon BO, Kim M, Hong S, Ryu J, Song SJ, Khim JS (2014) Microphytobenthos of Korean tidal flats: a review and analysis on floral distribution and tidal dynamics. Ocean Coast Manage 102:471-482

Paterson DM, Hagerthey SE (2001) Microphytobenthos in contrasting coastal ecosystems: biology and dynamics. In: Reise K (ed) Ecological comparisons of sedimentary shores, Book 151. Springer, Berlin, p 105-125

Paterson DM, Perkins R, Consalvey M, Underwood GJC (2003) Ecosystem function, cell micro-cycling and the structure of transient biofilms. In: Krumbein WE, Paterson DM, Zavarzin GA (eds) Fossil and recent biofilms: a natural history of life on Earth. Springer, Dordrecht, p 47-63

* Peletier H (1996) Long-term changes in intertidal estuarine diatom assemblages related to reduced input of organic waste. Mar Ecol Prog Ser 137:265-271

* Ratmaya W, Soudant D, Salmon-Monviola J, Plus M and others (2019) Reduced phosphorus loads from the Loire and Vilaine rivers were accompanied by increasing eutrophication in the Vilaine Bay (south Brittany, France). Biogeosciences 16:1361-1380

Redzuan NS, Underwood GJC (2020) Movement of microphytobenthos and sediment between mudflats and salt marsh during spring tides. Front Mar Sci 7:496

Riaux C (1983) Structure d'un peuplement estuarien de diatomées épipéliques du Nord-Finistère. Oceanol Acta 6:173-183

Riaux C, Germain H (1980) Peuplement de diatomées épipéliques d'une slikke de Bretagne Nord. Importance relative do genre Cocconeis Ehr. Cryptogam Algol 1: 265-280

Ribeiro L (2010) Intertidal benthic diatoms of the Tagus estuary: taxonomic composition and spatial-temporal variation. $\mathrm{PhD}$ dissertation, Universidade de Lisboa

Ribeiro L, Brotas V, Mascarell G, Couté A (2003) Taxonomic survey of the microphytobenthic communities of two Tagus estuary mudflats. Acta Oecol 24:S117-S123

* Ribeiro L, Brotas V, Rincé Y, Jesus B (2013) Structure and diversity of intertidal benthic diatom assemblages in contrasting shores: a case study from the Tagus estuary. J Phycol 49:258-270

Ribeiro L, Brotas V, Hernández-Fariñas T, Jesus B, Barillé L (2020) Assessing alternative microscopy-based approaches to species abundance description of intertidal diatom communities. Front Mar Sci 7:36

Rincé Y (1993) Les diatomées marines de la région de BasseLoire: inventaire, distribution spatio-temporelle et devinir expérimental des peuplements naturels d'écosystèmes ostréicoles. PhD dissertation, Université des Nantes

Round FE (1971) Marine benthic diatoms. Oceanogr Mar Biol Annu Rev 9:83-139

* Rovira L, Trobajo R, Leira M, Ibáñez C (2012) The effects of hydrological dynamics on benthic diatom community structure in a highly stratified estuary: the case of the Ebro Estuary (Catalonia, Spain). Estuar Coast Shelf Sci 101:1-14

* Sabbe K (1993) Short-term fluctuations in diatom numbers on an intertidal sandflat in the Westerschelde estuary (Zeeland, The Netherlands). Hydrobiologia 269-270:275-284

Sabbe K (1997) Systematics and ecology of intertidal benthic diatoms of the Westerschelde estuary (The Netherlands). $\mathrm{PhD}$ dissertation, Universiteit Gent 
Sabbe K, Vyverman W (1991) Distribution of benthic diatom assemblages in the Westerschelde (Zeeland, The Netherlands). Belg J Bot 124:91-101

Sabbe K, Vyverman W (1995) Taxonomy, morphology and ecology of some widespread representatives of the diatom genus Opephora. Eur J Phycol 30:235-249

Sabbe K, Vanelslander B, Ribeiro L, Witkowski A, Muylaert K, Vyverman W (2010) A new genus, Pierrecomperia gen. nov., a new species and two new combinations in the marine diatom family Cymatosiraceae. Vie Milieu 60: 243-256

Sahan E, Sabbe K, Créach V, Hernandez-Raquet G, Vyverman W, Stal LJ, Muyzer G (2007) Community structure and seasonal dynamics of diatom biofilms and associated grazers in intertidal mudflats. Aquat Microb Ecol 47: 253-266

Savelli R, Dupuy C, Barillé L, Lerouxel A and others (2018) On biotic and abiotic drivers of the microphytobenthos seasonal cycle in a temperate intertidal mudflat: a modelling study. Biogeosciences 15:7243-7271

Scholz B, Liebezeit G (2012) Microphytobenthic dynamics in a Wadden Sea intertidal flat-Part I: seasonal and spatial variation of diatom communities in relation to macronutrient supply. Eur J Phycol 47:105-119

Tempère J, Peragallo H (1907-1915) Diatomées du Monde Entier Collection Tempère et Peragallo, 2nd edn. Text. Chez J. Tempère, villa Andrée-Lucie à Arcachon (Gironde)

ter Braak CJF, Smilauer P (2002) CANOCO reference manual and CanoDraw for Windows user's guide: software for canonical community ordination (version 4.5). Microcomputer Power, Ithaca, NY

Thornton DCO, Dong LF, Underwood GJC, Nedwell DB (2002) Factors affecting microphytobenthic biomass, species composition and production in the Colne Estuary (UK). Aquat Microb Ecol 27:285-300

Trites M, Kaczmarska I, Ehrman JM, Hicklin PW, Ollerhead J (2005) Diatoms from two macro-tidal mudflats in Chignecto Bay, upper Bay of Fundy, New Brunswick, Canada. Hydrobiologia 544:299-319

Trobajo R, Sullivan M (2010) Applied diatom studies in estuaries and shallow coastal environments. In: Smol JP, Stoermer EF (eds) The diatoms: applications for the environmental and earth sciences. Cambridge University Press, Cambridge, p 309-323

Underwood GJC (1994) Seasonal and spatial variation in epipelic diatom assemblages in the Severn estuary. Diatom Res 9:451-472

Underwood GJC, Barnett M (2006) What determines species composition in microphytobenthic biofilms? In: Kromkamp JC, de Brouwer JFC, Blanchard GF, Forster RM, Créach V (eds) Functioning of microphytobenthos in estuaries. Royal Netherlands Academy of Arts and Sciences, Amsterdam, p 123-140

Editorial responsibility: Ilana Berman-Frank,

Haifa, Israel

Reviewed by: 3 anonymous referees
Underwood GJC, Kromkamp J (1999) Primary production by phytoplankton and microphytobenthos in estuaries. Adv Ecol Res 29:93-153

Underwood GJC, Paterson DM (2003) The importance of extracellular carbohydrate production by marine epipelic diatoms. Adv Bot Res 40:184-240

* Underwood GJC, Provot L (2000) Determining the environmental preferences of four estuarine epipelic diatom taxa: growth across a range of salinity, nitrate and ammonium conditions. Eur J Phycol 35:173-182

Underwood G, Phillips J, Saunders K (1998) Distribution of estuarine benthic diatom species along salinity and nutrient gradients. Eur J Phycol 33:173-183

Underwood GJC, Perkins RG, Consalvey M, Hanlon ARM, Oxborough K, Baker NR, Paterson DM (2005) Patterns in microphytobenthic primary productivity: species-specific variation in migratory rhythms and photosynthesis in mixed-species biofilms. Limnol Oceanogr 50:755-767

*Van Colen C, Underwood GJC, Serôdio J, Paterson DM (2014) Ecology of intertidal microbial biofilms: mechanisms, patterns and future research needs. J Sea Res 92:2-5

van der Werff A, Huls H (1957-1974) Diatomeeenflora van Nederland, Vols 1-10. De Hoef, Abcoude

*Vanelslander B, De Wever A, Van Oostende N, Kaewnuratchadasorn $P$ and others (2009) Complementarity effects drive positive diversity effects on biomass production in experimental benthic diatom biofilms. J Ecol 97:1075-1082

*Vieira S, Ribeiro L, Marques da Silva J, Cartaxana P (2013) Effects of short-term changes in sediment temperature on the photosynthesis of two intertidal microphytobenthos communities. Estuar Coast Shelf Sci 119:112-118

*Virta L, Gammal J, Järnström M, Bernard G, Soininen J, Norkko J, Norkko A (2019) The diversity of benthic diatoms affects ecosystem productivity in heterogeneous coastal environments. Ecology 100:e02765

Virta L, Soininen J, Norkko A (2020) Stable seasonal and annual alpha diversity of benthic diatom communities despite changing community composition. Front Mar Sci $7: 88$

Witkowski A, Lange-Bertalot H, Metzeltin D (2000) Diatom flora of marine coasts. I. In: Lange-Bertalot $\mathrm{H}$ (ed) Iconographia Diatomologica, Vol 7. ARG Gantner Verlag, Ruggell, p 1-925

Witkowski A, Pilzen M, Kort R, Rhiel E and others (2004) Investigations on the seasonal succession of Wadden Sea inhabiting diatoms at Dangast (North Sea, German Bight) over a one year period. Vie Milieu 54:181-189

Witkowski A, Sullivan MJ, Bogaczewicz-Adamczak B, Bąk M, Rhiel E, Ribeiro L, Richard P (2012) Morphology and distribution of a little known but widespread diatom (Bacillariophyceae), Navicula spartinetensis Sullivan et Reimer. Diatom Res 27:43-51

Submitted: June 15, 2020

Accepted: April 30, 2021

Proofs received from author(s): June 23, 2021 